\title{
Author Index Volume 109 (1997)
}

\author{
Abdulali, S., 341 \\ Niziol, W., 67 \\ Earl, R., 13 \\ Pesce, H., 357 \\ Kottwitz, R.E., 225 \\ Skowroński, A., 99 \\ Lauritzen, N., 1 \\ Tamagawa, A., 135 \\ Medori, C., 197 \\ Yin, L., 49 \\ Nacinovich, M., 197
}

